\title{
Steroids from the Leave of Persicaria perfoliata (L.) H. Gross
}

\author{
Md. Sagar Hossain ${ }^{1}$, N. M. Mofiz Uddin Khan², Md. Saiful Quddus ${ }^{3}$ \\ and A. M. Sarwaruddin Chowdhury ${ }^{1}$ \\ ${ }^{1}$ Department of Applied Chemistry and Chemical Engineering, Faculty of Engineering \\ University of Dhaka, Dhaka-1000, Bangladesh \\ ${ }^{2}$ Dhaka University of Engineering and Technology (DUET), Gazipur-1700, Bangladesh \\ ${ }^{3}$ Bangladesh Council of Scientific and Industrial Research (BCSIR), Dhaka-1205, Bangladesh
}

(Received: May 15, 2019; Accepted: June 16, 2019; Published: July 22, 2019)

\begin{abstract}
$\beta$-sitosterol (1) and $\beta$-sitosterol-D-glucoside (2) were isolated from the dichloromethane soluble fraction of a methanol extract of the leave of Persicaria perfoliata. The crude fraction was subjected to antimicrobial screening and brine shrimp lethality bioassay, where moderate antimicrobial activity was observed against most of the test organisms was seen. The hexane soluble fraction also displayed significant cytotoxic activity with $\mathrm{LC}_{50} 0.64 \mu \mathrm{g} / \mathrm{ml}$ in brine shrimp lethality bioassay. This is the first report of occurrence of these compounds from this plant.
\end{abstract}

Key words. Persicaria perfoliata, Polygonaceae, $\beta$-sitosterol, $\beta$-sitosterol-D-glucoside, Brine shrimp lethality, antimicrobial screening.

\section{Introduction}

Persicaria perfoliata (L.) H. Gross (Bengali name- Chataamrail; Family- Polygonaceae) forms a highly branched vine capable of growing over trees and shrubs. Its light blue-green leaves are triangular and 1-3 inch wide, thin, jointed; highly branched stems are green to reddish-green in color; curving spines are present on the leaf stalks, stems and underside of leaves along the veins; a leaf-like cup of tissue surrounds the stem at the base of the leaf stalk. Flowers are inconspicuous; metallic blue, berry-like, pea-sized $(5 \mathrm{~mm})$ fruits are present from mid-July through the first frost (Bown, 1995; Xingzhong and Sneden, 1999). In China, the plant is known for its traditional medicinal importance, especially for herpes zoster and extensive burns (Xingzhong and Sneden, 1999; Xingzhong et al., 2000). Previous phytochemical investigations with $P$. perfoliata led to the isolation of neoflavonids, diferuloyl esters of sucrose, smiglaside E, heloniosides phenylpropanoids and chalcins (Xingzhong and Sneden, 1999;
Xingzhong et al., 2000). Five diferuloyl esters of sucrose: 6'-acetyl-3,6-diferuloylsucrose (helonioside B), 2,4',6'-triacetyl-3,6-diferuloylsucrose, 1,2',6'triacetyl-3,6-diferuloyl-sucrose, 1,2',4',6-tetraacetyl3,6 diferuloylsucrose and 2',6'-diacetyl-3,6diferuloylsucrose, were iso-lated, along with the 1,3, 6-tri-p-coumaroyl-6'-feruloylsucroses, vanicoside A and vanicoside $\mathrm{B}$, from the whole plant of $P$. perfoliatum by various chromatographic methods (Xingzhong and Sneden, 1999; Xingzhong et al., 2000).

\section{Materials and Methods}

General experimental procedure: ${ }^{1} \mathrm{H}-$ and ${ }^{13} \mathrm{C}$ NMR spectra were recorded using a Bruker AMX$400(400 \mathrm{MHz})$ instrument, in deuterated chloroform and the $\delta$ values for ${ }^{1} \mathrm{H}$ and ${ }^{13} \mathrm{C}$ spectra were referenced to the residual nondeuterated solvent signals.

Correspondence to: A. M. Sarwaruddin Chowdhury, E-mail: sarwar@du.ac.bd; Tel.: +88-02-9661900-73, Extn. 7389.

DOI: https://doi.org/10.3329/bpj.v22i2.42314 
Plant material: P. perfoliata was collected from northern region of Bangladesh. It was identified at Bangladesh National Herbarium, Dhaka, where a voucher specimen has been deposited (DACB- 2773). The plant was washed with water to remove mud and dust particles and cut into pieces. The plant was first dried at room temperature and then in the oven at a reduced temperature (not more than $50^{\circ} \mathrm{C}$ ). The dried plant materials was ground to powder by a cyclotec grinder (200 meshes) and the powder was stored for extraction in an air tight bottle.

Extraction and isolation: The air dried and powdered plant material (400 g) was soaked in methanol (95\%) for 6 days for the purpose of cold extraction. The extract was then filtered through fresh cotton bed and finally Whatman No.1 filter paper. The filtrate was concentrated with a rotary evaporator at low temperature $\left(40-45^{\circ} \mathrm{C}\right)$ and under reduced pressure. The weight of the crude extract was about $15 \mathrm{~g}$. The concentrated methanol extract was fractionated by the modified Kupchan partitioning method into $n$-hexane, dichloromethane and ethyl acetate soluble fractions. Evaporation of solvents afforded $n$-hexane $(2.2 \mathrm{~g})$, dichloromethane $(7.7 \mathrm{~g})$ and ethyl acetate $(4.1 \mathrm{~g})$ soluble fractions. The dichloromethane soluble fraction $(7.7 \mathrm{~g})$ was further fractionated by column chromatography (CC) over silica gel (70-230 meshes) using mixtures of $n$-hexane, dichloromethane and methanol with increasing polarities to give 20 fractions, each $50 \mathrm{ml}$. Preparative thin layer chromatography of fractions 05 and 14 over silica gel $\mathrm{F}_{254}$ using $65 \%$ dichloromethane in $n$-hexane afforded two compounds, $\beta$-sitosterol (1) and $\beta$-sitosterol-Dglucoside (2).

Bioassays: The antimicrobial activity of the dichloromethane soluble extractive was determined by the disc diffusion method (Bauer et al., 1966). The extractive was dissolved separately in chloroform and applied to sterile filter paper discs at a concentration of $500 \mu \mathrm{g} / \mathrm{disc}$ while Kanamycin disc $(30 \mu \mathrm{g} / \mathrm{disc})$ was used as standard. For cytotoxicity screening DMSO solutions of the test samples were applied against Artemia salina for 24 hours in a simplified ex vivo assay (Meyer et al., 1982). Solutions of varying concentrations such as 400,200,100, 50, 25, 12.50, $6.25,3.125,1.563,0.781 \mu \mathrm{g} / \mathrm{ml}$. Then each of these test solutions was added to test tubes containing 10 shrimps in simulated brine water $(5 \mathrm{ml})$. After 24 hours, the median lethal concentration $\left(\mathrm{LC}_{50}\right)$ of the test samples was obtained by a plot of percentage of the shrimps killed against the logarithm of the sample concentration. Here, vincristine sulphate was used as positive control.

\section{Results and Discussion}

The ${ }^{1} \mathrm{H}-(400 \mathrm{MHz})$ and ${ }^{13} \mathrm{C}-(100 \mathrm{MHz})$ NMR spectra of the compound $\mathbf{1}$ displayed signals characteristic of a steroidal compound and, in fact, they were identical to those available in the laboratory for standard sitosterol. Co-TLC of compound 1 with authentic sitosterol established its identity as $\beta$-sitosterol (Khatun et al., 2012).

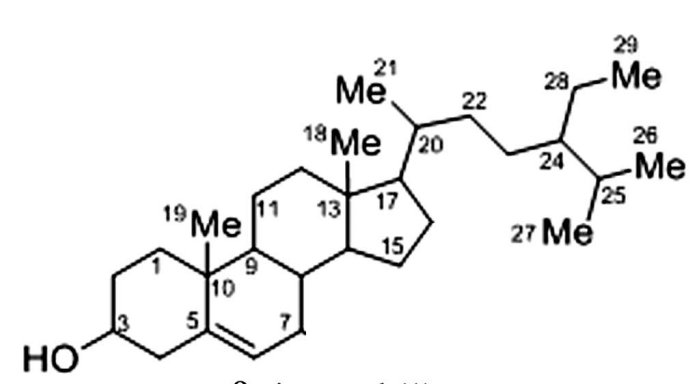

$\beta$-sitosterol (1)

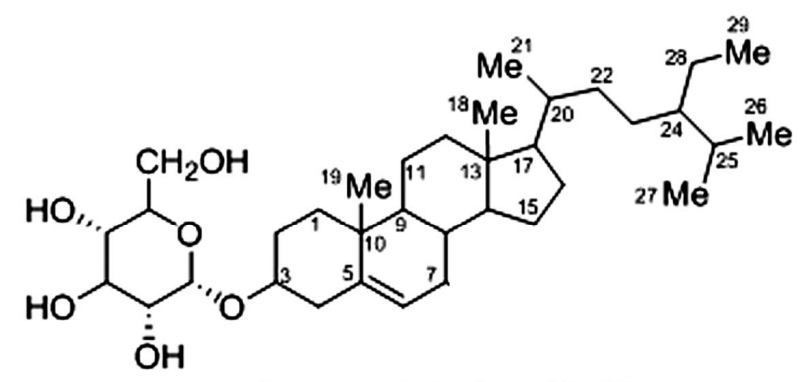

$\beta$-sitosterol-D-glucoside (2) 
The ${ }^{1} \mathrm{H}-\mathrm{NMR}$ spectrum (400 $\mathrm{MHz}, \mathrm{CDCl}_{3}$ ) of compound 2 showed signals indicative of a steroidal glycoside. The ${ }^{13} \mathrm{C}-\mathrm{NMR}(100 \mathrm{MHz})$ spectrum exhibited 35 carbon resonances suggestive of a steroidal glycoside. Comparison of the ${ }^{1} \mathrm{H}$ - and ${ }^{13} \mathrm{C}$ NMR spectral data with those recorded for $\beta$ sitosterol-D-glucoside (Khatun et al., 2012) as well as co-TLC with previously isolated $\beta$-sitosterol-Dglucoside confirmed the identity of compound 2 as $\beta$ sitosterol-D-glucoside.

Although both sitosterol and its glucoside are well known to occur in many plants, this is the first report of their occurance in $P$. perfoliata.
In the antimicrobial screening (Nahar et al., 2008; Gazi et al., 2007), the dichloromethane soluble extractive of the plant exhibited mild antimicrobial activity against most of the test organisms listed in table-1. The zone of inhibitions produced by the dichloromethane extract ranged from $08-10 \mathrm{~mm}$, at a concentration of $500 \mu \mathrm{g} / \mathrm{disc}$. Following the procedure of Meyer (Meyer et al., 1982), the lethality of $n$ hexane and dichloromethane soluble fractions were screened by brine shrimp lethality bioassay for probable cytotoxic activity. The $\mathrm{LC}_{50}$ obtained from the best-fit line slope were found to be $1.3 \mu \mathrm{g} / \mathrm{ml}$ and $0.64 \mu \mathrm{g} / \mathrm{ml}$ for $n$-hexane and dichloromethane extract, respectively (table 2) which were comparable to the positive control vincristine sulphate $\left(\mathrm{LC}_{50} \mu \mathrm{g} / \mathrm{ml}\right)$.

Table 1. Antimicrobial activity of DCM soluble fraction of $P$. perfoliata and Kanamycin.

\begin{tabular}{lcc}
\hline & \multicolumn{2}{c}{ Diameter of zone of inhibition in mm } \\
\cline { 2 - 3 } Test bacteria and fungi & DCM soluble fraction $(500 \mu \mathrm{g} / \mathrm{disc})$ & Kanamycin $(30 \mu \mathrm{g} / \mathrm{disc})$ \\
\hline Bacillus cereus $(\mathrm{BTCC}-19)$ & 10 & 36 \\
B. megaterium $(\mathrm{BTCC}-18)$ & 10 & 36 \\
B. subtilis & 10 & 36 \\
Staphylococcus aureus $(\mathrm{BTCC}-43)$ & 9 & 35 \\
Escherichia coli (BTCC-172) & - & 38 \\
Salmonella typhi & 10 & 35 \\
Shigella boydii & 8 & 38 \\
Vibrio mimicus & 10 & 34 \\
Candida albicans & 10 & 35 \\
Aspergillus niger & 10 & 38 \\
\hline
\end{tabular}

Table 2. Results of brine shrimp lethality of $P$. perfoliata extractives and vincistine sulfate.

\begin{tabular}{lc}
\hline Test Samples & $\mathrm{LC}_{50}(\mu \mathrm{g} / \mathrm{ml})$ \\
\hline Vincristine sulphate (Standard) & 0.33 \\
$n$-Hexane soluble fraction & 1.3 \\
DCM soluble fraction & 0.64 \\
\hline
\end{tabular}

\section{Acknowledgement}

The authors wish to thank the Bangladesh Council of Scientific and Industrial Research (BCSIR) under Ministry of Science and Technology, Government of the People's Republic of Bangladesh for financial support.

\section{References}

Bauer, A.W., Kirby, W.M.M., Sherris, J.C. and Turck, M. 1966. Antibiotic susceptibility testing by a standardized single disc method. Am. J. Clin. Pathol. 45, 493-496.

Bown, D. 1995. Encyclopaedia of Herbs and Their Uses, Dorling Kindersley, London, ISBN 0-513-020-31. 
Gazi, H.R., Kabir, S., Rahman, M.S., Chowdhury, A.M.S., Begum, B. and Rashid, M.A. 2007. Antimicrobial and cytotoxic activities of the crude extracts of Hopea scaphula. Dhaka Univ. J. Pharm. Sci. 6, 131-133.

Khatun, M., Billah, M. and Quader, M.A. 2012. Sterols and sterol glucoside from Phyllanthus Species. Dhaka Univ. J. Sci. 60, 5-10.

Meyer, B.N., Ferringni, N.R., Puam, J.E., Lacobsen, L.B., Nichols, D.E. and McLaughlin, J.L. 1982. Brine shrimp: a convenient general bioassay for active constituents. Planta Med. 45, 31-32.

Morales, G., Sierra, P., Mancilla, A., Paredes, A., Loyola, L.A., Gallardo, O. and Borquez, J. 2003. Secondary metabolites from four medicinal plants from northern Chile: antimicrobial activity and biotoxicity against Artemia salina. J. Chil. Chem. Soc. 48, 13-18.
Nahar, K., Khan, M.G.U., Rahman, M.S., Begum, B. and Rashid, M.A. 2008. Antimicrobial and cytotoxic activities of Bryophyllum daigremontianum. Dhaka Univ. J. Pharm. Sci. 7, 99-101.

Xingzhong S. and Sneden A.T. 1999. Neoflavonoid from Polygonum perfoliatum. Planta Med. 65, 671-673.

Xingzhong S., Michael L., Zimmermann, J.M.C. and Sneden, A.T. 2000. New sucrose phenylpropanoidesters from Polygonum perfoliatum. J. Nat. Prod. 63, 1094-1097. 